\title{
Covid-19 Pandemic Lockdown: The Consequences Towards Project Success in Malaysian Construction Industry
}

Muneera Binti Esa, Farah Salwati Binti Ibrahim*, Ernawati Binti Mustafa Kamal

Construction Management Department, School of Housing, Building and Planning, Universiti Sains Malaysia, Gelugor, Penang, 11800 , Malaysia

\begin{tabular}{l} 
A R T I C L E I N F O \\
\hline Article history: \\
Received: 11 August, 2020 \\
Accepted: 06 September, 2020 \\
Online: 20 October, 2020 \\
\hline Keywords: \\
Covid-19 \\
Lockdown \\
Movement Control Order (MCO) \\
Malaysia Construction Industry \\
Project Success
\end{tabular}

\section{Introduction}

The 2019 Novel Coronavirus or Covid-19 is currently a pandemic issue that is spreading globally [1] which have affected 9.54 million people and 485,000 recorded in 215 countries up to $25^{\text {th }}$ June 2020 [2]. This pandemic was first identified in Wuhan City, located in Hubei Province in China $[1,3,4]$. Due to that, on January 11, 2020, the Covid-19 was recognised as a global pandemic by the World Health Organization. Then, on $30^{\text {th }}$ January 2020, the Emergency Committee of the World Health Organization (WHO) has declared the on-going Covid-19 outbreak to be a global Public Health Emergency of International Concern (PHEIC) which the PHEIC defined as an "extraordinary event" that "constitute a public health risk to other States through

${ }^{*}$ Corresponding Author: Farah Salwati Binti Ibrahim, Construction Management Department, School of Housing, Building and Planning, Universiti Sains Malaysia, 11800 Gelugor, Penang, Malaysia, farahsalwati@gmail.com wWW.astesj.com

https://dx.doi.org/10.25046/aj0505119 the international spread of disease" and "potentially require a coordinated international response", this definition implies the situation faced is a serious, sudden, unusual or unexpected situation that can give a huge insinuation to the public health beyond the State's national border and it may require immediate internal action [5]. In the situation of Covid-19, the PHEIC is significant to prevent the outbreak from affecting other countries with weak health system.

Due to rapid spreading of Covid-19 among the people, a lockdown has been implemented in several countries affected by the virus to disconnect the virus from spreading. The lockdown is divided into two categories which are the nationwide traffic restriction and stay at home movement [6]. Hence, many sectors were advised to stop their operations and services during the lockdown including the construction sector [7]. In Malaysia's situation, the Covid-19 is not as worse as in United State of 
America (USA), Russia, United Kingdom, Brazil, Spain, Italy and China. However, tight measures have been implemented by the Malaysia government to prevent this pandemic from wide spreading. Like other countries, Malaysia has also implemented nationwide traffic restriction and stay at home order since $18^{\text {th }}$ March 2020 until this date (RMCO). The government has imposed restriction in term of movement control order (MCO) with a special standard operation procedure (SOP) and not a tight lockdown as China's.

Furthermore, Covid-19 pandemic is not just affecting human health but also bringing the economy to the worst level where all the industry was severely hit. Therefore, construction activities were also facing project suspension and cancellation due to shortage of materials, equipment and parts because of the lockdown. Hence, most of the supplier had to close their businesses and they cannot deliver the requested materials during that time. Moreover, there are several consequences of lockdown to the construction industry as recorded in United State of America (USA) in term of time, cost, resource availability and construction worker layoff [8]. As for Malaysia, the government has also halted all construction progress within MCO phase 1 to phase 3 .

In line with the issue, this paper intends to explore the consequences of the Movement Control Order (MCO) towards the project success in Malaysia's context. Hence, this paper will be explaining the theoretical background about the movement control order (MCO) and the related project success factors. Then, methodology used for this study will also be enlighten, followed by the findings, discussions and the conclusion for this study. It is important to acknowledge the consequences of the MCO towards project success because the result from this study will assist the government and industry to plan a post-Covid-19 roadmap to enhance the construction industry in the future specifically to overcome the issues of the consequences among affected construction players like contractor.

\section{Theoretical Background}

This section provides a theoretical background for the paper. The first part discusses the Movement Control Order in Malaysia's context, followed by the literature of project success and the current state of the Malaysian construction industry.

\subsection{Lockdown Alternative in Malaysia: Movement Control Order} (MCO)

Movement Control Order (MCO) known as cordon sanitaire refers to the restriction on the people movement from one place to another either locally or internationally which can cause spreading of unexpected disease or viruses. This movement control has been used as a preventive measure to stop the spreading of unwanted diseases or viruses. Moreover, the MCO in Malaysia was enforced under the Control and Prevention of Infectious Diseases Act 1988 and the Police Act 1967 [9]. In Malaysia, the government has implemented four (4) types of MCO as this date according to the situation needed with differing Standard of Operation (SOP) which are;

\subsubsection{Movement Control Order (MCO)}

MCO applied nationwide in Malaysia where most of the main sectors are not allowed to operate during this time and most of the workers are encouraged to work from home or stay at home to minimize the virus transmission started from $18^{\text {th }}$ March until $28^{\text {th }}$ April 2020 in three phases with every phase allocating 14 days of quarantine time [10]. To ensure the MCO successfully breaks the chain of Covid-19, there are six (6) restrictions or orders imposed during the MCOs period which are [9];

- Complete restriction of movement and gatherings nationwide, including religious activities, sports, social and cultural events. To enforce this restriction, all houses of worship and business premises are to be closed, except supermarkets, public markets, sundry shops and convenience stores selling essential goods.

- Complete travel restriction for all Malaysians going overseas and mandatory to undergo health checks and voluntary selfquarantine for 14 days.

- Complete restriction to foreign visitors and tourists into Malaysia.

- Closing of all kindergartens, public and private schools including day schools and residential schools, international schools, Tahfiz centres and all other institutions of learning in primary, secondary and pre-university levels

- Closing of all public and private institutions of higher learning nationwide including skills training institutes.

- Closing of all government and private premises except those involved in essential services such as water, electricity, energy, telecommunications, post, transportation, irrigation, oil, gas fuel, lubricants, broadcasting, finance, banking, health, pharmacy, fire prevention, prisons, ports, airports, security, defence, cleaning, food supply \& retail.

\subsubsection{Enhanced MCO (EMCO)}

This EMCO phase started from $27^{\text {th }}$ March and it only applied within certain areas with high cases of Covid-19 such as in Simpang Renggam, Johor; Sungai Lui, Selangor; City One, Kuala Lumpur; Selangor Mansion and Malayan Mansion, Kuala Lumpur; Jalan Masjid India, Kuala Lumpur and Wholesale Market in Selayang. In this EMCO, the government has announced this control to curb the spreading of the Covid-19 as well as to make it easier for the authorities to trace the cases unit by unit throughout the EMCO period. Therefore, the government has categorised the affected area in three colour zoning (red zone, yellow zone and green zone) as a differentiation to show the level of the affected area according to the numbers of Covid-19 active cases recorded. The red zone represents the area with more than 41 cases recorded and will be designated as EMCO area for fourteen (14) days or until the cases reduced to satisfied level. Meanwhile, for the yellow zone, it represents areas that recorded cases within 1-40 cases and for the green zone, represent "zero" cases area. There are a few accomplishments in the EMCO which are;

- All residents are prohibited from exiting the EMCO area throughout the EMCO.

- All non-residents and visitors are prohibited from entering the area throughout the EMCO

- All business activities are to be closed, except for the shops selling daily essential items in buildings

- Residents are allowed to use food delivery services

- A medical base will set up in the EMCO area.

- All in and out points of the EMCO will be sealed. 
- The Royal Malaysian Police (PDRM), Malaysian Armed Forces (ATM), Angkatan Pertahanan Awam (APM) and Jabatan Sukarelawan Malaysia (RELA) will act as administers in the EMCO area.

\subsubsection{Conditional $\mathrm{MCO}(\mathrm{CMCO})$}

Then, after the number of new Covid-19 cases have dropped to below 100 cases per day, the government has announced Conditional MCO (CMCO) as Phase 4 MCO starting on 4th May 2020 until $^{\text {th }}$ June 2020 [11], seeing a more relaxed implementation of CMCO regulation compared to the previous MCO regulations where certain sectors are allowed to reopen their business. The main purpose of this $\mathrm{CMCO}$ is to help the government regenerate and regain the momentum of Malaysia's economy, a step up from essential sectors only previously. Thus, starting 4th May 2020, the sectors that have obtained the permission to reopen their business from MITI (Ministry of International Trade and Industry) are allowed to operate but with a tight SOP (Standard Operational Procedures) determined by the government. There are few conditions and requirements that need to be fulfilled by the employers and employees in preventing the virus from spreading in their workplace including the construction sectors. According to the Prime Minister, within the MCO phase 1 to phase 3 period, the government has lost around RM 2.4 billion per day, meaning the total losses is around RM63 billion until $1^{\text {st }}$ May 2020 and if the MCO continues for one more month, the overall total losses will reach RM98 billion [11]. Related to that, the construction sector also estimated about RM 11.6 billion per day in losses as stated by Minister of Work Department, Dato' Sri Hj Fadillah in Bernama TV interview session on $5^{\text {th }}$ May 2020. Therefore, the implementation of CMCO is important for the government and industry to generate income but the prevention of the Covid-19 from spreading is still highly prioritised.

\subsubsection{Recovery MCO (RMCO)}

Starting on 10th June until 31st August 2020, the RMCO will take over as an exit strategy for the MCO and CMCO, where in this phase more economic sectors are allowed to be operated, sport and recreational as well as domestic travelling also are allowed but with a tight SOP. Moreover, education sectors are starting to gradually reopen in phases as in 24th June, only form 5 and 6 starts their school session while kindergarten will reopen on July, 1st. In the construction industry, the RMCO facilitated the industry to increase their productivity to produce sufficient construction materials to be supplied, as more skilled workers and working time returns back to normal.

Somehow, the MCOs, as well as the CMCO and RMCO with tight SOP, hugely impacted the construction industry either the established companies or small and medium companies. The consequences are not only related to the financial aspects but also impacting the project success as well as the project performance. Due to that, the productivity of the project performance has dropped and to deliver a project is seen to be hard during this time.

\subsection{Project Success}

In defining the project success, it is vital to clearly understand the terms of project success to avoid misleading information to this study. The definition of a project success is broad, ambiguous and subjective [12-14] as well as multidimensional in concepts [14-
16] based on the process and the nature of the project [17]. Project success is frequently defined by the previous authors as the achievement of the project's objective, which in construction development, the project can be classified as project success when it efficiently achieved the iron triangle of time, cost, and scope or quality of the project outcome [18-20]. Moreover, [21] has defined "success" as the accomplishment of an aim in which the outcome is favourable.

Meanwhile, [22] expressed that project success is an accumulation of factors such as timely completion, within the budget, according to the specification and customer satisfaction. Then, [23] have defined the project success according to the project level where the project duration, monetary cost (budgeting) and project performance are highlighted as the key project success in their perspective. Additionally, there are a variety of factors that contribute to the project success other than factors mentioned above which the factors are according to the specific objectives for each of the projects such as safety, leadership, communication, teamwork, cognitive skill and so on [24]. Overall, project success is not just about completion of a project within the defined scope, time, and cost, nonetheless it is also about gaining the customer acceptance, stakeholder satisfaction, commercialization, and future project opportunity $[25,26]$. Otherwise, for current construction industry, defining and measuring success lead to discussions on efficiency and effectiveness of the organizational, team and individual performance in managing the project lifecycle [18]. Despite that, there are different parties involved in a project such as the client, architect, contractor, and various surveyors and engineers which each of them will have his or her view of success according to their job scope [27]. Therefore, there is no common set of project success definition agreed yet due to the nature of the projects which are unique and differs widely in the practice.

According to the [25] there are two types of project success that needs to be precisely understood the differences between it; which are the project success "factors" and the project success "criteria". The Project success factors are related to the elements of a project that when it is influenced, it will increase the likelihood of success and act as the independent variables that make success more likely. Moreover, it is also referred to 'how to achieve' the project success [28]. Meanwhile, the Project success criteria is a measurement that used to judge on the success or failure of a project; these are the dependent variables that measures the success by focusing on "what to achieve" in the project. Besides, the success factors presence the inputs to the management system that directly or indirectly contribute to the success of a project, while success criteria are measures by which success of a project is judged [22]. Numerous previous studies on project success concentrated on identifying the success factors rather than success criteria as their subject because it is important to identify the success factors for a project before establishing which criteria should be used to judge or determine the project success [29]. Due to this explanation, this study indicates that the project success factors are the relevant type to be studied in this research because at the end of this research, the outcome will contribute to the body of knowledge for the industry and the government on what factors are affected due to the MCO in delivering a successful project; beneficial for them to overcome the issue based on the factors produced by this study.

Besides the listed project success factors as discussed above, the safety and health condition either the workers or the environment of construction sites and regulatory compliance should be one of the factors in successfully deliver the project 
according to the current situation faced. It is because to ensure the project can be operated as usual without distressed project progress, the construction players need to play important roles in closely implementing the SOP announced by the government.

\subsection{Current Situation in Malaysia Construction Industry}

On 13th of April 2020, the Prime Minister has announced that the main services including construction sector is allowed to operate during the CMCO but with a strict SOP [11]. Later on $30^{\text {th }}$ May, there are 28 of workers affected by Covid-19 in a construction site located in Jalan Ampang [30]. Hence, to overcome the spreading of Covid-19 in construction site while still be in full operation, the government has declared a specific SOP for construction sectors on $1^{\text {st }}$ May 2020 stated under Act 520. This SOP also applicable for all construction sector related professional services (Quantity surveyor, engineers, architect firm etc.). Moreover, in the SOP, the developers and contractors are fully responsible to ensure their site workers and staffs follows all the terms and conditions particularly to keep the workers' health and hygiene as a priority. Besides, any violation of the SOP will cause the construction site to be closed.

As at $15^{\text {th }}$ May 2020, CIDB has declared that within $20^{\text {th }}$ April to $18^{\text {th }}$ May 2020 , there are 515 or $11 \%$ of the construction site in the whole Malaysia successfully complied to the SOP, meanwhile, 167 (4\%) are non-compliance (warning notice) and seven (7) are ordered to be closed. Besides, there are 3,870 (85\%) construction sites still not resuming their project at that time. Furthermore, as recorded on $22^{\text {nd }}$ June 2020 through CIDB Telegram Channel, the operating construction site increased to 2245 (84\%). Meanwhile, $437(16 \%)$ construction site were issued warning notice and 19 (1\%) of the construction site are ordered to be closed because of SOP non-compliance such as not implementing Covid-19 screening tests for the workers, not registered with CIDB, does not provide Covid-19 health supervisor and $90 \%$ not practising the SOP properly in the construction site. From the increment of the project which is successfully compliance to SOP, it was proven that the construction players have a good awareness and understanding regarding to SOP imposed by the government.

There are 15 actions highlighted by the government in the SOP for construction industry including the (1) Preparation of information and Documentation for the project (2) Workers management (3) Workers transportation vehicle (4) Workers movement (in-out construction site) (5) transportation of construction materials and supplies (6) Information blasting and awareness regarding the SOP in construction site (7) Emergency management and response (8) contact tracing (9) the entrance of the construction site/premise (10) Compliance that need to be implement while carrying out construction work (11) Toilet management (12) Time-break management (13) Procedure for returning from work (14) Accommodation at construction site/premises and (15) Record all the related data in for SOP compliance as required by the government [31].

Starting from the first phase until the third phase of MCO most of the construction site is directed to be closed by the government for approximately 6 weeks except for critical development categories. Due to this, most of the project schedule is interrupted and causes delay in delivering the project. The delay is not only related to the project progress on site; it also affected the suppliers who deliver the materials due to the restricted movement from one place to another place. The machinery availability is also limited and this caused hectic to the construction players. To overcome the lagging progress, extra work from all parties, additional time and cost should be prepared by the developers and contractors. Additionally, the limited number of workers are allowed to work on-site in conjunction with the social distancing hugely impacted the project's progress as well as productivity. In getting more precise information regarding the current scenario of the construction industry in Malaysia and the consequences that the construction players are facing now, this research is essential to be explored.

\section{Methodology}

In producing accurate and apparent data, a qualitative method of research was used for this study. A qualitative method chosen for this study is due to the appropriate method in collecting the data where the respondents experience the issue or problem under the study and the data was produced subjectively from their minds [32]. A stratified random sampling technique was used in this study in which simple random subsample was taken from different strata in the same or equal characteristic [33]. This technique is less in error and enhanced the precision of the sample selection. In this case, the population of this study is Malaysian construction players and the strata consists of contractors. Then, for subsample selection, a simple random sampling is used for each of the strata group. This study was conducted in Klang Valley and Penang where both of these areas are currently active in developing new construction project.

Table 1: Respondents Profile

\begin{tabular}{|c|c|c|c|c|c|c|c|c|}
\hline Respondents & R1 & $\mathrm{R} 2$ & R3 & R4 & R5 & R6 & R7 & R8 \\
\hline Designation & 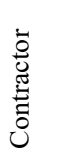 & 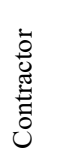 & 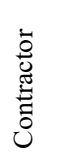 & 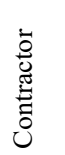 & 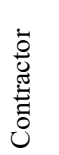 & 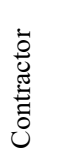 & $\begin{array}{l}\stackrel{0}{0} \\
\stackrel{0}{0} \\
\stackrel{\Xi}{0} \\
0\end{array}$ & 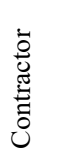 \\
\hline $\begin{array}{c}\text { Years of } \\
\text { Experience }\end{array}$ & 5 & 10 & 20 & 10 & 15 & 1 & 7 & 10 \\
\hline $\begin{array}{l}\text { Current } \\
\text { Project }\end{array}$ & 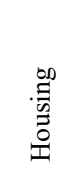 & 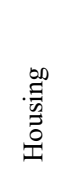 & 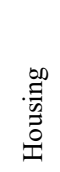 & 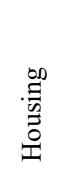 & 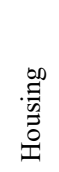 & 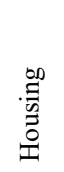 & 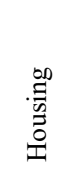 & 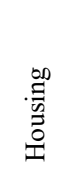 \\
\hline $\begin{array}{c}\text { Expected } \\
\text { Completion } \\
\text { Time } \\
\text { Before } \\
\text { MCO }\end{array}$ & $3 y$ & $3 y$ & $4 y$ & $8 m$ & $3.5 y$ & $3.2 \mathrm{y}$ & $4 y$ & $4 y$ \\
\hline $\begin{array}{c}\text { Expected } \\
\text { Cost Before } \\
\text { MCO } \\
\text { (RM'000) }\end{array}$ & 50 & 900 & $\begin{array}{l}1.5 \\
\text { mil }\end{array}$ & 470 & $\begin{array}{l}1.5 \\
\text { mil }\end{array}$ & $\begin{array}{l}130 \\
\text { mil }\end{array}$ & NA & $\begin{array}{l}42 \\
\text { mil }\end{array}$ \\
\hline $\begin{array}{c}\text { Expected } \\
\text { Completion } \\
\text { Time After } \\
\text { MCO }\end{array}$ & TBA & $3.2 \mathrm{y}$ & $4.6 y$ & $11 \mathrm{~m}$ & $4 y$ & $3.5 y$ & $4.7 \mathrm{~m}$ & $4.4 y$ \\
\hline $\begin{array}{c}\text { Expected } \\
\text { Cost After } \\
\text { MCO } \\
\left(\mathrm{RM}^{\prime} 000\right)\end{array}$ & 70 & 900 & $\begin{array}{l}1.51 \\
\text { mil }\end{array}$ & 611 & $\begin{array}{l}1.8 \\
\text { mil }\end{array}$ & $\begin{array}{l}132 \\
\text { mil }\end{array}$ & 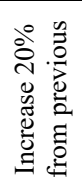 & $\begin{array}{l}42 \\
\text { mil }\end{array}$ \\
\hline
\end{tabular}


Due to the MCO, most of the construction company halted the construction activities and the employees are encouraged to work from home. Hence, the telephone conversation is selected as the medium for interviewing them. Before conducting the interview, the researchers have set the eligibility criteria of the respondent for this study such as respondents is a contractor, have an active project, involved in the construction project in Klang Valley and Penang, and registered with CIDB. Firstly, the researchers had selected a few companies through CIDB website, then the researchers browsed the selected company's website to identify their on-going project. After being satisfied with the criteria, the invitation email was sent to the respondents using their registered email in CIDB website. From 20 emails sent out, only 8 contractors gave feedback and willing to be part of this study. According to [34], the amount of the useable data obtained from each respondent is more important than the number of the participants in which the greater the amount of useable, the fewer the number of participants is needed. It also supported by [35] where the number of interviews between five and twenty-five interviews is enough to understand about their experience in that situation. Hence, eight respondents are adequate in getting feedback related to this study. Table 1 shows the respondents' profile.

An exploratory study has been conducted in this study by using semi-structured interview with the contractors based on their experience during the MCO. There are 17 questions were developed by the researchers which were designed to allow respondents to express their opinion and experience freely during the interview session. The interview was divided into 3 sections involving the social demographic which includes working experience in the construction field, current project, expected completion date \& total development cost before MCO and expected completion date \& total development cost after MCO. The next section is to measure their understanding and awareness on the SOP for the construction industry during the MCO and RMCO. Then, the last section is about the consequences of the MCO towards project success. The duration for each of the interview session was about 30 to 40 minutes. The questions for the interview were developed based on the previous literature and focused on factors generated by the previous project success factors namely; time, cost, human resource, resource availability, safety prevention and regulatory compliance.

Then, the data obtained from the interview were analysed using content analysis which according to the [36] the data for qualitative mainly consist of words, which can have several meanings and could lead into wrong interpretation, therefore the content analysis is used because it can identifying the quote, coding the quotes and categorising the codes and also mapping approach being used to find the relationship between the different categories. Thus, content analysis was being used in this study to analyse the data gathered from the interview by using Nvivo Software. Nvivo Software can quickly run the frequent word in the script to find the same theme, provides word cloud and the connection between the theme can easily be identified. During the telephone conversation, the researchers had recorded the interview session and the data was transcribed manually by the researchers. Then, the transcribed script was analysed using Nvivo which then the results are based on the highest theme that shows in the shape of boxes. The bigger box shows the high consequences event and vice versa. From the content analysis, this study found that there are 6 themes listed as the main consequences' factors of the MCO towards the project success.

\section{Finding and Discussion}

From the consequences of the MCO towards project success, this paper has classified the consequences into two which are in the perspective of negative where the factors turns the project to not achieving the success and positive views for the factors that help the project successful delivered because it is important to address both of these views to help the government, industry and construction players understand the current scenario as well as to guide them for planning post-Covid-19 for the industry.

\subsection{General Consequences of MCO}

From the content analysis, 6 themes were emerged from this study. These themes were further grouped into two general themes which are negative consequences and positive consequences of MCO towards the project success. The following findings and discussions are structured around themes that were mentioned by respondents as shown in Table 2. Meanwhile, the subthemes were considered as the factors influencing the theme in achieving the project success was shown in Figure 1 as the conceptual framework for this study. The first theme that was identified was time, which consists of delay on hand overring the project due to delay in material supplying, changing in work breakdown as well as rescheduling the project timeline because of time-lapsed during the MCO period. Cost emerged as the second theme, comprised of cost in providing hygiene kits (face mask, hand sanitizer, soap), Covid-19 tests for workers, cost in appointing Covid-19 Health Supervisor to oversee Covid-19 prevention on-site and cost in providing transportation for the workers to promote social distancing among the workers. Then, the safety aspect becomes the third theme with several subthemes which are significant in preventing the workers from the pandemic cluster like compulsory recording the daily temperature, social distancing, Covid-19 test for all foreign workers, workers management (movement, arrangement, job scope), workers hygiene, contact tracing, break time management, worker's residential management and regularly educate the workers about the pandemic. The fourth theme is related to the regulatory compliance which is the most significant in ensuring the project can be operated and the authority reserves the right to authorize or terminate the site due to noncompliance of SOP. The human resource theme consisted of the level of workers expertise (skilled, semi-skilled and unskilled), limited of workers at any one time at the same space, low productivity due to limited workers and working time as well as the termination of workers to reduce the project cost. The final and the sixth theme that was observed was the resource availability in the market and site which are limited including the material, equipment as well as skilled workers. 
Table 2: The Results of the Consequences of MCO towards Project Success

\begin{tabular}{|c|c|c|c|c|c|c|c|c|c|c|c|c|c|c|c|c|c|c|c|c|c|c|c|c|c|}
\hline \multirow[t]{2}{*}{ Respondent } & \multicolumn{4}{|c|}{ TIME } & \multicolumn{4}{|c|}{ COST } & \multicolumn{9}{|c|}{ SAFETY } & \multicolumn{2}{|c|}{$\begin{array}{l}\text { REGULATION } \\
\text { COMPLIANCE }\end{array}$} & \multicolumn{4}{|c|}{$\begin{array}{c}\text { HUMAN } \\
\text { RESOURCES }\end{array}$} & \multicolumn{2}{|c|}{$\begin{array}{c}\text { RESOURCE } \\
\text { AVAILABILITY }\end{array}$} \\
\hline & DP & RE & DM & BR & HK & COV & HS & TR & DT & SD & cov2 & WM & WH & CT & TBM & WRM & EDU & FULL & VIS & WE & LW & LP & $\mathbf{W L}$ & LME & LSW \\
\hline R1 & 1 & 1 & 1 & & 1 & 1 & 1 & & 1 & I & 1 & 1 & 1 & & I & 1 & 1 & 1 & 1 & 1 & 1 & & & 1 & 1 \\
\hline R2 & I & I & & & I & / & & & / & / & / & / & I & I & / & & & / & I & & I & I & & & I \\
\hline R3 & I & / & / & & I & I & & & / & / & & & / & & & & & I & I & & I & / & & I & \\
\hline R4 & I & I & / & & / & I & I & & I & I & I & & & & I & / & & I & I & I & I & / & & I & \\
\hline R5 & I & 1 & I & & I & I & & 1 & 1 & 1 & 1 & 1 & & & & & & I & 1 & I & 1 & I & & I & \\
\hline R6 & I & & & I & I & I & 1 & & 1 & 1 & & 1 & I & I & & & I & I & 1 & I & & I & I & 1 & I \\
\hline R7 & I & 1 & & I & I & 1 & I & I & I & I & 1 & & & 1 & & & & 1 & 1 & I & 1 & I & & 1 & I \\
\hline R8 & 1 & 1 & & 1 & 1 & 1 & & & 1 & & 1 & 1 & & 1 & 1 & I & & 1 & 1 & 1 & 1 & & 1 & 1 & 1 \\
\hline TOTAL & 8 & 7 & 4 & 3 & 8 & 8 & 4 & 2 & 8 & 7 & 6 & 5 & 4 & 4 & 4 & 3 & 2 & 8 & 8 & 6 & 7 & 6 & 2 & 7 & 5 \\
\hline
\end{tabular}

\begin{tabular}{|l|l|}
\hline Subthemes & Abb. \\
\hline Delay on hand overring the project & DP \\
\hline Rescheduling the project & RE \\
\hline Delay on material supply & DM \\
\hline Change the work breakdown & BR \\
\hline Cost for providing hygiene kit (face mask, hand sanitizer, soap) & HK \\
\hline Covid-19 test & COV \\
\hline Cost appointing the Covid-19 Health Supervisor & HS \\
\hline Providing worker's transportation & TR \\
\hline Daily Temperature & DT \\
\hline Social distancing & SD \\
\hline Covid-19 test for all foreign workers & COV2 \\
\hline Workers management (movement, arrangement, job scope) & WM \\
\hline Workers hygiene & WH \\
\hline
\end{tabular}

\begin{tabular}{|l|l|}
\hline Subthemes & Abb. \\
\hline Contact tracing & CT \\
\hline Time break management & TBM \\
\hline Worker's residential management & WRM \\
\hline Educate the workers about the pandemic & EDU \\
\hline Fully compliance the SOP regulation & FULL \\
\hline An unexpected visit from the authority & VIS \\
\hline Workers expertise & WE \\
\hline Limited workers & LW \\
\hline Low productivity & LP \\
\hline Workers layoff/termination & WL \\
\hline Limited material \& equipment in the market and on-site & LME \\
\hline Limited Skill workers & LSW \\
\hline & \\
\hline
\end{tabular}




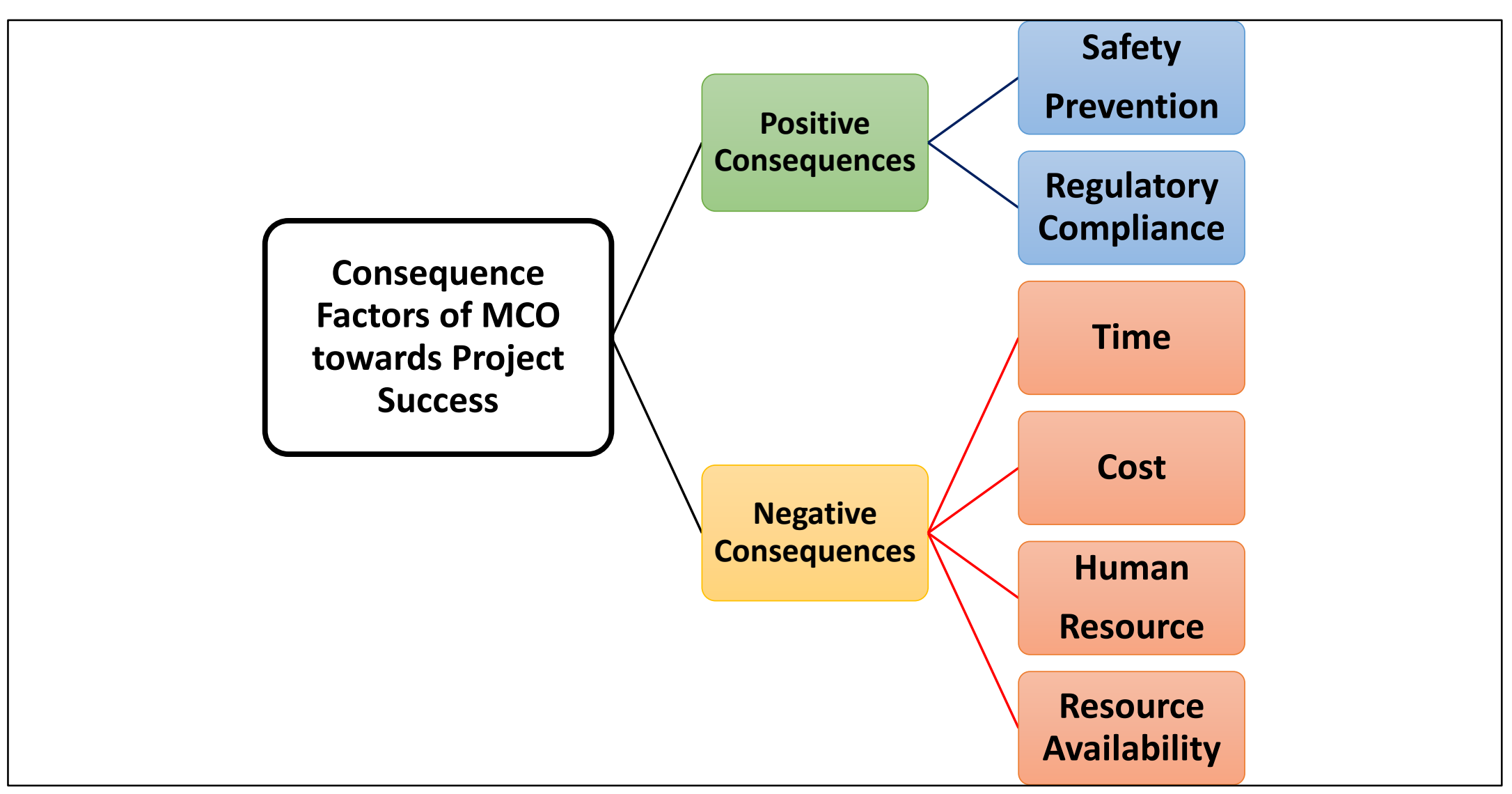

Figure 1: The Conceptual Framework of Consequences of MCO towards Project Success 


\subsection{Negative Consequences}

The consequences of the MCO towards the project success gave negative impact mainly to (i) time, (ii) cost, (iii) human resources and (iv) resource availability in the market as well as onsite. Therefore, the construction players and government need to give more attention to these negative consequences factors in order to overcome the project delay, project losses and to optimize the project timeline and the project performance.

\subsubsection{Time}

Time is considered as one of the main factors that gave high impact to the project success, the project is considered successful when it can be delivered on time to the client within the budget and good in quality $[37,38]$. In the event of any delay, it will cause an extension of time and rise in cost, in which the project failed to achieve the success [25]. In regard to time, it has found that the $\mathrm{MCO}$ has delayed the handing over of the project to the client and this were affected by several issues like delayed material supply due to the manufacturers halting their business, as well as the supplier, cannot across the state or region during the MCO period. Due to that, the contractors need to reschedule the project timeline and change the work breakdown which invited stress among the contractors to fulfil the client requirement with tight budgeting in limited working time. Somehow, there are respondents mentioning that they are facing the extended time in their project of 2 to 7 months to complete the project development. As quoted by most of the respondents regarding the consequences of time during the MCO in Malaysia such as;

\section{Respondent's Feedback on Consequences of Time -}

\section{Delay \& Extended of time}

"delay on hand over the project, delay on material supply most of the work breakdown need to change and rearrange the time schedule"

"it's important to cover all the previous delay work"

"difficulties to hand over the project which delayed 2 months from the actual delivery time"

"our project delay for 2 months from the previous completion time"

"project timeline due to the limited time in term of working hours, material delivery and number of workers allowed in any one time. So, the project will be delayed for about 7 months from the actual timeline"

\subsubsection{Cost}

In term of cost, the respondents have mentioned that they are facing cost increment between RM 100,000 to RM 300,000 for their housing project of which 2 respondents facing a huge cost increment due to their big project involving the development of public project housing under Armed Forces. Meanwhile, another 4 respondents are involved in affordable housing project. Moreover, there are 2 respondents remaining at the same cost as the previous costing before the MCO because their project is already at the final stage therefore not much work to revise. Based on the respondent's feedback, the increment of the project costing because of two additional requirements highlighted in the SOP, the first cause is providing all the workers with face mask, hand sanitizer, keeping the site in good hygiene also cost of regularly sanitize the areas frequently used by the workers. Then, the second cause is related to Covid-19 tests that is compulsory to the workers especially the foreign workers before resuming their work on-site. Furthermore, 4 of respondents mentioned that appointing a Covid-19 team or health supervisor in the construction site will also increase the cost of their project. Below is the respondent's explanation regarding the consequences of MCO towards the costing aspect in construction project;

\section{Respondent's Feedback on Consequences of Cost -}

Provide the workers with safety kits

"We also need to provide face mask, hand sanitizer and hand soap to promote hygiene among the workers, but the cost of providing the face mask is high due to daily usage"

"increased total development cost from the original because according to the SOP we need to provide face mask, hand sanitizer"

\section{Respondent's Feedback on Consequences of Cost -} Provide the workers with Covid-19 Test

"The most influential cost aspect is COVID-19 tests for the workers especially the foreign worker, you already know that the price for 1 test per person is between RM 150 to RM 300, so if we have about 20 persons foreign workers, so it will cost us a lot"

"running Covid-19 test to all workers especially the foreign workers before we resume work on site. The covid-19 test is expensive and you can calculate by yourself how many should we spend on that test if we have more than 10 workers, it will cost thousands of Ringgit Malaysia, huge cost"

\section{Respondent's Feedback on Consequences of Cost - \\ Providing Health Supervisor/Covid-19 Team at site}

"we also need to appoint a health-supervisor as representative to manage and monitor the safety on-site including to monitor our compliance with all the SOP. This will also be an additional cost that we need to bear"

"we also need to appoint a health supervisor on-site to monitor the regulation compliance among the staffs and labourers on-site who can update us on the daily SOP compliance on-site"

\subsubsection{Human Resources}

The third negative consequences of MCO towards project success is focused on human resource which included the limited numbers of workers and skilled workers allowed to work in one time in the same area or space in practicing social distancing among the workers. Due to that, it will give a negative impact to the project productivity, previously the workers managed to complete $30 \%$ to $50 \%$ of work in one area or space with a few workers in one day but for this current situation, the productivity slid down between $10 \%$ to $30 \%$ according to the project. Other than that, the MCO also causes some of the unskilled workers layoff due to limited budget to hire them without any relevant skills. The skilled and semi-skilled workers are seen to be significant in this constricted project timeline [37].

\section{Respondent's Feedback on Consequences of Human Resource -}

\section{Limited number of workers \& Skilled workers}

"limited number of workers allowed to work in one time to ensure the social distancing are implemented, this will affect the productivity of work per day and the daily percentage of project completion"

"the limited numbers of workers allowed to work in one time also get us headache because some work need lots of people in one time so we need to arrange it by minimizing the workers and job scope" 
"to maintain our project financial, some of unskilled workers are laid off because we need a skilled worker to work faster and reduce the error risk"

\subsubsection{Resource Availability}

Finally, limited resource availability on-site and in the market such as manpower, materials and machinery are also a challenging situation during the MCO period and causes time as well as cost overrun. According to [37], the construction delays causing risks on time and cost are including the materials, manpower, plants and equipment, changes, scheduling and control as well as government relation which all of these are related to the MCO situation.

\section{Respondent's Feedback on Consequences of Resource Availability}

"Resource are very limited in current situation due to the manufacturer are closed for a few weeks, so the supplier cannot get their sources and the limited resource in market has cause the price to go up. Other than that, the supplier also cannot deliver the exact amount that we need in one time because they need to get permission from the police before they can travel and deliver the material to us. So, we need to hold some of the work because of inadequate material"

"limitation on resource availability either in term of human, materials and machineries. All are interconnected by each other"

\subsection{Positive Consequences}

Besides the negative consequences of $\mathrm{MCO}$, there are also positive consequences that give good impact to the construction industry. According to the respondents, all of them agreed that the MCO is a good initiative to disconnect the Covid-19 from spreading especially in the construction site where most of the time the social distancing and cleanliness are hard to practice. But, through this study, it can be seen that with the new SOP imposed by the government, changed the construction site into a better site and human resource management. The improvement of the safety practice aspect and the regulatory compliance by the construction players are the positive consequences that has been practised in the construction industry since the Covid-19 pandemic.

\subsubsection{Safety Prevention}

The safety in construction site is significant to ensure the site is free from hazards and to minimize the accidents in construction site [39]. At the same time, to increase the probability of project success, attention to construction safety need to be heightened in preventing the workers and other related parties from illness and accidents thus avoiding unnecessary cost and delays [40]. In the pandemic situation, every worker, supplier, staffs or any person who visited the construction site must be thermally scanned before entering the site. Moreover, the workers especially the foreign workers are compulsory to get Covid-19 test before they are allowed to work in construction site. Other than that, the contractor, as well as the construction workers, are responsible for managing the social distancing and hygiene in their construction site. In conjunction with that, the contractors practicing a proper workers' residential, time-break schedule (to make sure the canteen is not crowded in one time), worker's transportation for purpose of social distancing and control the worker's movement to minimize the spreading of the Covid-19.

Respondent's Feedback on Consequences of Safety Prevention

"daily temperature must be recorded for all workers before entering the site"

"compulsory for covid-19 test for all workers before our project resume back as usual to prevent the pandemic"

"For daily check, the body temperature is recorded for all of the person working or entering the site including the worker, supplier, site clerk, engineer and other related parties"

"All foreign and local workers are compulsory to be tested for covid-19 before they are allowed to work"

"make a marked area for practicing social distancing in worker's residential, café area, prayer room. We also record all the workers details and movements for contact tracing as well as the project detail"

"managing the workers on-site include managing their residential, time break scheduling, record all the movements and also provide transportation for our workers and we are strictly concerned regarding the hygiene"

\subsubsection{Regulatory Compliance}

In construction industry, the regulatory compliance is essential because failure to meet the regulation requirement means the project failed to meet the core requirement that has been decided [41]. In this research, it was found that this theme is significant in determining whether the construction site is allowed to operate or not because the authorities will randomly conduct an unexpected checking to the construction site and if the site is not properly implementing the SOP, their project will get warning notice or ordered to be closed. This tight regulation is good to practice in the construction industry to make sure all the construction workers and staffs are in a safe condition. The respondents also aware about the important to comply the SOP on the site.

\section{Respondent's Feedback on Consequences of Regulation Compliance}

"This part is hard to comment because it was related to the government order, so like it or not we need to comply to the SOP for construction because once we agree with that SOP, we need to adhere to it. The authorities will visit our project in unexpected time so we need to always be ready in term of project details, project documentation, workers detail and move in and out parties in the site for contact tracing"

"if you comply to all the SOP so you will be safe even if the authorities make unexpected spot check to your site. Then, we need to prepare a proper documentation management to record the project detail and the workers. Actually, it is difficult to manage all this, but if you want to save your project like it or not you need to do it"

\subsection{Discussion}

Based on the 6 consequence factors that have been decided in this study, the regulatory compliance became the main factor to determine if the project either is allowed to continue to work or closed during this pandemic issue. Once the project is directed to be closed because of non-compliance of the SOP, the project will be facing delay, losses and the cost will keep increasing day by day and in the end the project will be stuck and abandoned. Hence, the regulatory compliance is essential in this pandemic situation. 
Then, followed the safety prevention factors, in which the safety precaution is important to prevent the workers and the construction site from being a new cluster for spreading the virus. There are several preventive actions that has been introduced by the Ministry of Health in the SOP and this safety prevention is connected to the regulatory compliance. The awareness and understanding regarding these two issues are seen to be positive due to the number of projects allowed to operate is getting higher.

Another 4 factors such as time, cost, human resource and resource availability is turned to negative aspect during this pandemic issue due to the movement control order for 6 weeks. The project timeline and costing need to rescheduled and recalculated which caused extended time and increasing costs. However, the project will still need to be done even if it will stress the contractors and workers to deliver the project within the new adjusted time and cost. In conjunction with that, the low production by manufacturers for suppling the materials will cause an extension of time because there is higher demand but low in supply. It also happened to the supply of machinery and limited skilled workers in this hectic situation. Furthermore, the contractors need to be more particular with all the issues in the construction site to minimize the error in the project progress and at the same time comply to the SOP especially in practising social distancing, hygiene and worker's health. From the discussion above, the MCO has gave high impact to the 6 consequence factors mentioned above and the government should give due concern to all the factors to facilitate the construction players especially those categorized as small and medium construction companies because most of them are affected during this MCO.

Due to these 6 factors, there are still have a few factors that attached with these factors, but in this current situation only these 6 factors are mainly have given high influenced to the project either it can be successfully delivered or not. Thus, the limited information from the respondents also being the limitation in this research due to the telephone conversation which sometimes having distressing because of the noise, unfocused of respondents while answered the questions and no face reaction can be detected.

\section{Conclusion and Future Work}

Based on the negative and positive consequences recorded through the interview session, the MCO has given lots of hindrances to the construction players compared to the positive consequences on the project success. The extension of time in delivering the project, the increased project costing and limited resource have hastened the project to achieve the project success. Currently, to facilitate the construction industry survival in this critical situation especially for the small and medium contractors' companies, CIDB has announced "CIDB Prihatin Initiative" with nine (9) schemes such as deferment on the levy payment, deferment of construction personnel skill training and fee payment for skill competency assessment. Also, the compulsory requirement for Covid-19 test is a burden to the contractors because of its cost, however, on $23^{\text {rd }}$ June 2020, the government facilitate by CIDB and SOCSO (Social Security Organization) has launched a new initiative to help the construction players on this issue by providing them with a free Covid-19 test for the foreign workers especially for the small and medium construction company.

Through all the discussion in this paper, it can be concluded that MCO has given a lot of negative impacts towards the project success whereby the contributing factors to project success such as time, cost and resource availability are affected by the MCO. With limited additional time and tight budget has caused stress among the contractors especially for the project that needs more than RM 100,000 additional cost to complete their project (Refer Table 1). In another view, MCO has taught people about the selfcare in preventing the Covid-19 especially in term of regularly practising good hygiene and social distancing. At the same time, it was observed that the SOP compliance level amongst construction players is seen to be better and this new norm should be maintained in the construction industry to avoid the second wave of Covid-19 in Malaysia. For further works, this research will continue to be conducted on other construction players including the AEC (Architecture, Engineering and Construction) company in Malaysia to investigate the impact of MCO to their organization.

\section{Conflict of Interest}

The authors declare no conflict of interest.

\section{Acknowledgment}

This research was supported by the Fundamental Research Grant Scheme (FRGS), Ministry of Higher Education [Grant No: FRGS/1/2019/TSSI11/USM/02/1]; Academic Research Grant School of Housing, Building and Planning, Universiti Sains Malaysia (1001.PPBGN.808005) and USM Fellowship Scheme

\section{References}

[1] X. Gao, J. Yu, "Public governance mechanism in the prevention and control of the COVID-19 : information, decision-making and execution," Journal of Chinese Governance, $\quad \mathbf{0}(0), \quad 1-20, \quad 2020$, doi: $10.1080 / 23812346.2020 .1744922$.

[2] WHO, Coronavirus Disease (COVID-19) Outbreak Situation, World Health Organization, 2020.

[3] L. Wang, Y. Wang, D. Ye, Q. Liu, "A review of the 2019 Novel Coronavirus (COVID-19) based on current evidence," International Journal of Antimicrobial Agents, 105948, 2020, doi:10.1016/j.ijantimicag.2020.105948.

[4] T. Singhal, "A Review of Coronavirus Disease-2019 ( COVID-19)," The Indian Journal of Pediatrics, 2020, doi:10.1007/s12098-020-03263-6.

[5] World Health Organization, WHO Emergencies Coronavirus Emergency Committee Second Meeting, 2020.

[6] Z. Yuan, Y. Xiao, Z. Dai, J. Huang, Y. Chen, "A Simple Model to Assess Wuhan Lock-down Effect and Region Efforts during COVID-19 Epidemic in China Mainland," Bulletin of the World Health Organization, 2020.

[7] S. Brown, L. Claeys, "Six Steps Construction Companies Can Take to Ride Out the Coronavirus Shock," Associated General Contractors of America, 2020.

[8] AGC, "Construction Layoffs Spread Rapidly as Coronavirus Shuts Down Projects, In Contrast to Job Gains Through February in Most Metroos," The Associated General Contractor of America, 2020.

[9] PMO, Speech By Prime Minister of Malaysia on 16 March 2020, 1-4, 2020.

[10] PMO, Perutusan Perdana Menteri Malaysia 18 Mac 2020, 1-6, 2020.

[11] PMO, Teks Perutusan Khas Perdana Menteri Malaysia Sempena Hari Buruh 1 Mei 2020, 1-17, 2020. 
[12] D. Chan, "Cognitive Misfit of Problem-Solving Style at Work: A Facet of Person - Organization Fit," Organizational Behavior and Human Decision Process, 68(3), 194-207, 1996.

[13] S.M. Sabry Elattar, "Towards Developing an Improved Methodology for Evaluating Performance and Achieving Success in Construction Projects," Scientific Research and Essay, 4(6), 549-554, 2009.

[14] S.M.H.M. Al-tmeemy, H. Abdul-Rahman, Z. Harun, "Future Criteria for Success of Building Projects in Malaysia," International Journal of Project Management, 29, 337-348, 2011, doi:10.1016/j.ijproman.2010.03.003.

[15] R. Atkinson, "Project Management: Cost, Time and Quality, Two Best Guesses and A Phenomenon, Its Time to Accept Other Success Criteria," International Journal of P, 17(6), 337-342, 1999.

[16] A.J. Shenhar, J.J. Renierg, "Improving PM : Linking Success Criteria to Project Type," in Southern Alberta Chapter, Project Management Institute, Symposium "Creating Canadian Advantage through Project Management", Calgary, May 1996., 12, 1996.

[17] L.A. Ika, "Project Success as a Topic in Project Management Journals," Project Management Journal, 40(4), 6-19, 2009, doi:10.1002/pmj.

[18] R. Müller, K. Jugdev, "Critical success factors in projects: Pinto, Slevin, and Prescott - the elucidation of project success," International Journal of Managing Projects in Business, 5(4), 757-775, 2012, doi:10.1108/17538371211269040.

[19] R. Joslin, R. Müller, "The impact of project methodologies on project success in different project environments," 2015, doi:10.1108/IJMPB-032015-0025.

[20] M.M. Raziq, F.M. Borini, O.F. Malik, M. Ahmad, M. Shabaz, "Leadership styles, goal clarity, and project success: Evidence from project-based organizations in Pakistan," Leadership and Organization Development Journal, 39(2), 309-323, 2018, doi:10.1108/LODJ-07-2017-0212.

[21] Oxford Dictionary, Oxford Dictionry, 2019.

[22] L.D. Nguyen, S.O. Ogunlana, D.T. Xuan Lan, "A Study on Project Success Factors in Large Construction Projects in Vietnam," Engineering, Construction and Architectural Management, 11(6), 404-413, 2004, doi:10.1108/09699980410570166.

[23] M. Albert, P. Balve, K. Spang, "Evaluation of project success : a structured literature review," International Journal of Managing Projects in Business, 10(4), 2017, doi:10.1108/IJMPB-01-2017-0004.

[24] J. Zuo, X. Zhao, Q.B.M. Nguyen, T. Ma, S. Gao, "Soft skills of construction project management professionals and project success factors: A structural equation model," Engineering, Construction and Architectural Management, 25(3), 425-442, 2018, doi:10.1108/ECAM-01-2016-0016.

[25] T. Cooke-Davies, "The “"Real " Success Factors on Projects," International Journal of Project Management, 20, 185-190, 2002.

[26] P. Serrador, R. Turner, "The Relationship Between Project Success and Project Efficiency," Project Management Journal, 46(1), 30-39, 2015, doi:10.1002/pmj.

[27] V. Sanvido, F. Grobler, K. Parfitt, M. Guvenis, M. Coyle, "Critical Success Factors for Construction Projects," Journal of Construction Engineering and Management, 118(1), 94-111, 1992.

[28] W.M. Wan Abdullah, Critical Factors in Project Success: A Study of Public Sector Construction Projects in Malaysia., Universiti Malaysa, Malaysia, 2010.

[29] M. Podgórska, M. Pichlak, "Analysis of project managers' leadership competencies: Project success relation: what are the competencies of polish project leaders?," International Journal of Managing Projects in Business, 2019, doi:10.1108/IJMPB-08-2018-0149.

[30] M. Bavani, Developers, Contractors in KL Construction Sites to get Workers tested for Covid-19., The Star, 2020.

[31] N. National Security Council, Standard of Procedure for Construction Sector, 2020.

[32] J.. Creswell, J.. Creswell, Research Design Qualitative, Quantitative and Mixed Method Approaches, Fifth Edit, SAGE Publication, London, United Kingdom, 2018.

[33] Z. Mahmud, Hanbook of Research Methodology, A Simplified Version., Fourth Edi, UiTM Press, Kuala Lumpur, Malaysia, 2015.

[34] J.M. Morse, "Determining Sample Size," Qualitative Health Research, 10(1), $3-5,2000$.

[35] J.. Creswell, Research Design Qualitative, Quantitative and Mixed Method Approaches, 4th Editio, 2014, doi:10.1192/bjp.112.483.211-a.

[36] Z. Zakaria, N. Mohamed Ali, A.T. Haron, A. Marshall-Ponting, Z. Abd Hamid, "Exploring the Adoption of Building Information Modelling (BIM) in the Malaysian construction industry: A Qualitative approach.," International Journal of Research in Engineering and Technology, 2(8), 384395, 2013, doi:10.1017/CBO9781107415324.004.

[37] C. Ramanathan, S.P. Narayanan, A.B. Idrus, "Construction Delays Causing www.astesj.com
Risks on Time and Cost - a Critical Review," Australasian Journal of Construction Economics and Building, 12(1), 37-57, 2012.

[38] S.G. Tadewos, D. Patel, "Factors influencing Time and Cost Overruns in Road Construction Projects: Addis Ababa, Ethiopian Scenario : Review paper," International Research Journal of Engineering and Technology (IRJET), 5(1), 177-180, 2018.

[39] S. Kanchana, P. Sivaprakash, S. Joseph, "Studies on Labour Safety in Construction Sites," The Scientific World Journal, 1-6, 2015.

[40] V.K. Bansal, "Application of geographic information systems in construction safety planning," International Journal of Project Management, 29(1), 66-77, 2011, doi:10.1016/j.ijproman.2010.01.007.

[41] J.D. Schwierking, V.S. Anantatmula, "The Effective Practitioner Project Management and Regulatory Compliance: The Missing Ingredient?," Baltzer Science Publishers, (May), 48-61, 2015. 